\title{
Import Tariffs and Informal Labour Market: A Computable General Equilibrium (CGE) Analysis for Turkey
}

\author{
HALE AKBULUT* \\ Hacettepe University, Department of Public Finance \\ HÜSEYIN TAYLAN EĞEN \\ Hacettepe University, Department of Public Finance
}

\begin{abstract}
From the 1980s to onwards trade liberalization policies have been widely used in many countries. This process has significant impacts on many economic aspects one of which is on the labour market. However, the direction of the relationship between trade reforms and the labour market is controversial. This study aims to analyse the effects of a specific trade reform of import tariff changes on the formal and informal labour market for Turkey. For that purpose, we benefit from Computable General Equilibrium (CGE) Model that relies on nonlinear simultaneous equations. We construct an updated Social Accounting Matrix (SAM) which is compatible with our model. Our findings indicate that while there is a positive relationship between formal labour employment in total and import tariff rates, the negative relationship occurs between informal employment and tariff rates.
\end{abstract}

Keywords: Informal Labour; Import Tariffs; CGE; Turkey

JEL Classifications: C68, H20, H21, H30, F16

\section{Introduction}

By the post-Washington process, most of the countries started to apply liberalized trade policies. Developing of endogenous growth theories which mention the productivity-enhancing technology spill over effects of trade liberalization also serve this fact. From this point forth, trade liberalization has widely extended in recent decades. Consequently, after a sharp decline in 2009 following the 2008 global crisis, world trade to GDP reached 58.04\% in 2015 (World Bank, 2017).

Increase in trade liberalization often associates with increasing informality in the labour sector due to increased foreign competition. This effect is thought to be crucial, especially for developing economies. These economies face high informality rates since either people find it

\footnotetext{
*Akbulut: corresponding author; halepehlivan@hacettepe.edu.tr. Eğen tegen@hacettepe.edu.tr

(C) 2021 Hale Akbulut and Hüseyin Taylan Eğen. Licensed under the Creative Commons Attribution Noncommercial 4.0 Licence (http://creativecommons.org/licenses/by-nc/4.0/. Available at http://rofea.org.
} 
optimal or are restrained working in the informal sector. Firms may also find it optimal to employ formal and informal labour simultaneously to maximize their profits. Therefore, a substantial amount of employment is informal in the developing world.

Reducing the level of informal labour is one of the essential policies of governments since it is disturbing to economic development. For that matter, Turkey is no exception for having the presence of a large informal labour sector. By 2016, the unregistered rate of labour in Turkey is $33.5 \%$ of total employment (TURKSTAT), and $82.1 \%$ of this rate is coming from the agriculture (see Table A1 in Appendix for unregistered employment rates in Turkey in agricultural and non-agricultural sectors). The Republic of Turkey Ministry of Development ${ }^{1}$ has also determined one of its aims as the increase of formal labour and premium base in the Medium-Term Program of 2017-2019.

By dealing both with increasing trade in worldwide and the problem of informal employment, we; in this paper, try to examine the effect of a particular trade liberalization policy, namely, reduction in import tariffs on formal and informal labour. To the best of our knowledge, this paper is the first that analyses the relationship in a Computable General Equilibrium (CGE) framework for Turkey. We contribute to the literature by employing an updated Social Accounting Matrix (SAM) by using recent Input-Output (IO) table of 2012 featured by the Turkish Statistical Institute (TURKSTAT). Our study also contributes to understanding how the labour markets in developing countries adjust to trade liberalization reforms.

The organization of the remainder of the paper is as follows: In section 2, we provide the relevant literature, including studies that rely on both partial and general equilibrium analyses. Section 3 introduces the characteristics of the economic model, its equations, and evaluates the results under different policy scenarios. Section 4 presents some concluding remarks.

\section{Literature Review}

Although the informal economy is recognized as one of the principal economic problems, there is no consensus on the definition of it. According to European Union Commission, undeclared work means "any paid activities that are lawful as regards their nature but not declared to the public authorities, taking into account differences in the regulatory systems of member states" (EU Commission, 1998: 2). Nikulin (2016) states that this approach assumes that criminal activities and work that does not have to be declared are excluded. ILO (International Labour Organization) strongly mentions the difference between employment in the informal sector and informal employment. Accordingly, the informal activities are characterized in ILO (1972) by: (i) ease of entry, (ii) reliance on indigenous resources, (iii) family ownership of enterprises, (iv)

\footnotetext{
${ }^{1}$ It has been operating as The Presidency of the Republic of Turkey Directorate of Strategy and Budget since 2018 .
} 
small scale of operation, (v) labour-intensive and adapted technology, (vi) skills acquired outside the formal school system, and (vii) unregulated and competitive markets (p.6). The report also emphasizes that the informal sector activities are largely ignored, rarely supported, often regulated, and sometimes actively discouraged by the government.

More recent ILO and WTO (World Trade Organization) joint study of Bacchetta et al. (2009) defines informal workers as those who do not benefit from social security and are not protected by labour regulation. We also refer to that definition which has also been cited frequently throughout the literature (Munro, 2011).

Before handling the informal employment, mentioning the effects of informality on the entire economy may be helpful. Some researchers emphasize the positive impacts of the informal sector (e.g., Spiro 2005). Accordingly, the informal economy that arises from high tax rates makes governments realize that there is a limit on how much they can spend. This realization helps to eliminate excessive, wasteful spending, and inefficient regulations. Additionally, with the decreasing effects on the cost of labour and creating new job opportunities, it serves to reduce unemployment rates. The official sector then is forced to decrease costs and improve quality due to competition. Even so, the informality is usually considered to be harmful to the entire economy due to its substantial adverse consequences. Accordingly, the informal economy makes economic statistics less reliable and therefore harms the success of economic policies. It also hurts the tax base as it is impossible to tax unrecorded activities. Danopoulos and Znidaric (2007) state that with the informal economy, government fiscal policy performs ineffectively due to uncertainty about the actual amount of revenue. Furthermore, the informal economy is easy to operate in small-scale firms, which are usually unproductive and inefficient. Bacchetta et al. (2009) note that informality limits the potential for developing countries while benefiting from the integration into the world economy and state that "countries with above-average sized informal economies are more than three times as likely to incur the adverse effects of a crisis as those with lower rates of formality".

Shifting of employment from the formal sector to the informal sector could also be undesirable since worse working conditions and lower job quality identifies the informal sector (Goldberg and Pavcnik, 2003, p.2). Moreover, from the workers' perspective, the informal economy is characterized by lower incomes, less job security, and the absence of social benefits.

There are some attempts to explain the relationship between trade liberalization and the informal economy both theoretically and empirically in the literature. Accordingly, trade liberalization causes firms to face increased foreign competition. Firms may replace their workers with the ones who accept to work as informal to reduce production costs. Currie and Harrison (1997) confirm that for Morocco by finding that firms started to hire more temporary workers after liberalized trade reforms.

Empirical studies usually employ the removal of tariffs as a trade liberalization policy instrument since it is well measured relative to non-tariff barriers. From this point forth, there 
is vast literature examining the macroeconomic effects of tariff reductions. However, they usually focus on the influences on either poverty (e.g., Chitiga \& Mabugu, 2005; Khan, 2005; Raihan, 2010; Mohammed, 2016) or income distribution (e.g., Siddiqui et al., 1999; Siddiqui \& Iqbal, 2001). The literature for the effects on formal/informal labour is limited.

Goldberg and Pavcnik (2003) analyse the effect of trade liberalization in the form of tariff declines on the informal sector for two countries that experienced trade barrier reductions: Brazil and Colombia. They observe no relationship between tariff declines and increases in informal employment in Brazil, while this relationship is positive but small for Colombia. They also find that trade policy effects are dependent on the labour market institutions. Accordingly, firms are more likely to respond to increased competition by reducing formal employment when the labour market rigidities are significant. Munro (2011) also in his review of the empirical literature, points to several country-specific factors such as variations in labour market rigidity, capital mobility, level of economic development, heterogeneity of the informal workforce, technological intensity, and cultural norms as the determinants of the relationship between trade and informality.

Some studies which benefit from general equilibrium models (e.g., Chaudhuri \& Banerjee, 2007; Marjit \& Kar, 2007) have a specific focus on the impact of trade liberalization policies on the "wage" of the informal workers. Marjit and Kar (2007) test the effects of the withdrawal of protecting policies, such as tariffs or state subsidies.

The studies that examine the relationship between import tariffs and employment by using CGE framework are quite rare, and only some of them (e.g., Davies and Thurlow, 2010; Alia et al., 2015; Erero \& Bonga-Bonga, 2018) focus on the distinction of formal/informal employment markets. We do not refer to CGE studies that handle employment as a whole, but the review of Cirera et al. (2014) states that the synthesis of these studies suggests non-negative influences of trade liberalization on aggregate employment and moderate inter-sectorial labour reallocation impacts.

Of the CGE based studies that discriminate between formal and informal employment Davies and Thurlow (2010) find that trade liberalization reduces national employment in South Africa, while at the same time increase formal employment and hurts informal producers. Alia et al. (2015) evaluate the effects of some economic policies on the informal sector for Cameroon. They simulate the policy of rising salaries of civilian and military personnel followed by the reduction of import tax rate and conclude that this simultaneous policy is advantageous to the formal sector but less favourable to the informal sector. However, they do not simulate import tariff reduction solely. Erero and Bonga-Bonga (2018) analyse the effects of import tariff reduction for the Democratic Republic of Congo (DRC) and find that tariff reduction increases formal employment and output while hurting informal producers.

Briefly, studies that examine the effects of import tariffs on employment with a particular focus on formal/informal discrimination are very limited. To the best of our knowledge, our 


\section{AKBULUT, EĞEN Import Tariffs and Informal Labour Market}

study is the first that analyses the relationship with a CGE modelling approach for Turkey. Additionally, as empirical literature points to the role of country-specific factors, focusing on a single country is thought to be sensible.

\section{The CGE Modelling}

\subsection{The Structure of the Model}

In this section, we try to build our model based on the simultaneous equation system reflecting the functional and behavioural relations of economic agents. We adopt an open economy model as it is more realistic and operative to be able to observe trade variables.

We benefit from CGE modelling as it allows to test the effects of policy changes without the restrictive "all else equal" assumption of partial equilibrium framework. In this way, our methodology allows observing the effects of different policy changes on the entire economy simultaneously. Thanks to improvements in mathematical computation, CGE models can also easily be computed and has been used in economic literature, increasingly.

Determining the equations and mathematical formulations are generally based on the economic theory and some previous studies (e.g., Hosoe et al., 2010; Lofgren et al., 2002). However, we contribute to the literature by additionally discriminating between formal and informal labour. In the next step, we calculate parameters that satisfy the benchmark equilibrium of the economy. We develop a social accounting matrix of Turkey in 2002 in the context of the current project to calibrate those parameters ${ }^{2}$.

While constructing SAM, we employ the most recent IO table from TURKSTAT together with other data sources ${ }^{3}$. We also rely on evaluations of the studies that compose SAM for Turkey, previously (e.g., Telli, 2004; Erten, 2009). In the last step, we apply different scenario analyses to observe the effects of the changes in the tariff rate on the formal and informal labour markets. Finally, we evaluate our simulation results.

We design our CGE model based on a static multi-sectorial open economy framework ${ }^{4}$. By following Marjit and Kar (2007), we employ a full-employment model in a general equilibrium setting as the informal workers must find employment for survival. The sectors are determined to be compatible with the statistical classification of economic activities in the European

\footnotetext{
${ }^{2}$ For the structure of SAM see Table A2 and for the calibration results of the parameters see Table A3, A4 and A5 in Appendix.

${ }^{3}$ Data sources include but not limited to the Presidency of the Republic of Turkey Directorate of Strategy and Budget, Republic of Turkey Ministry of Treasury and Finance, Social Security Institution and The Central Bank of the Republic of Turkey. The complete data set is available upon request from the authors.

${ }^{4}$ We use GAMS software in CGE analysis. The computer codes are available upon request from the authors.
} 
Community, NACE Rev 2. and the Statistical Classification of Products by Activity in the European Economic Community, CPA-2008. Accordingly, we determine sectors as agriculture, mining, industry, energy, construction, and services. Economic agents are households, private enterprises, social security institution, government, and the rest of the world. Expenditures and revenues of each economic agent are assumed to be equal following the Walrasian general equilibrium approach. Under these presumptions, production, demand, external demand, and market clearing conditions constitute the four main equation blocks of CGE model.

\subsubsection{The Production Block}

The production block is designed by nested production functions which incorporate two types of labour (formal and informal) and aggregated capital. Producers employ factors of production until the marginal revenue of each factor is equal to its price to maximize their profits.

Production of output is designed as the Leontief combination of the intermediate inputs and the value-added. Value-added arises from the capital and the composite labour within Cobb-

Figure 1. Structure of the Production Technology

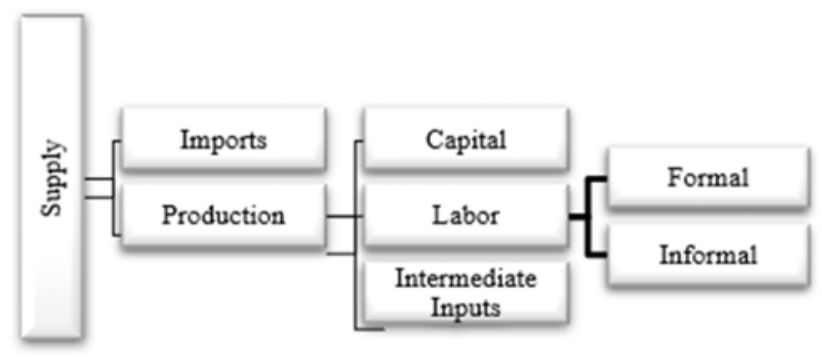

Douglas type production function. To determine output decisions and labour (formal/informal) input demands, firms are assumed to have several profit maximization problems. The first profit maximization problem of the firm to determine optimal capital and composite labour is

$$
\max _{Y_{j}, C_{j}, L_{j}} \operatorname{profit}=P Y_{j} Y_{j}-\sum_{j} P C_{j} C_{j}+P L_{j} L_{j}
$$

subject to

$$
Y_{\mathrm{j}}=\mathrm{b}_{\mathrm{j}} C_{\mathrm{j}}^{\beta \mathrm{c}_{\mathrm{j}}} L_{\mathrm{j}}^{\beta \mathrm{l}_{\mathrm{j}}}
$$




\section{AKBULUT, EĞEN Import Tariffs and Informal Labour Market}

which allows to determine capital demand (equation (2)) and composite labour (equation(3)) . In the second stage, firms decide to employ formal and informal labour according to following profit maximization problem.

$$
\max _{L_{j}, F L_{j}, I L_{j}} \text { profit }=P L_{j} L_{j}-\sum_{j} P F L_{j} F L_{j}+P I L_{j} L_{j}
$$

subject to

$$
L_{\mathrm{j}}=o_{\mathrm{j}}\left(\gamma f l_{\mathrm{j}} F L_{\mathrm{j}}^{\vartheta_{\mathrm{j}}}+\gamma i l_{\mathrm{j}} I L_{\mathrm{j}}^{\vartheta_{\mathrm{j}}}\right)^{\frac{1}{\vartheta_{\mathrm{j}}}}
$$

We modify standard approaches mentioned above with constant elasticity substitution (CES) function in the production of composite labour input to formulate the relationship between two types of labour and production. $\vartheta_{j}$ in the composite labour specification is elasticity of substitution between formal and informal labour. When $\vartheta_{j}=1$ formal and informal labour turns out to be perfect substitute and employment tends to be favour in the more productive labour input. Another extreme case occurs when $\vartheta_{j}=0$. In this case, composite labour equation will be Leontief type function where formal and informal labour are perfect complements.

In the third stage, firm's maximization problem below yields the remaining behavioural equation of the firms.

$$
\max _{Z_{j}, Y_{j}, X_{i j}} \text { profit }=P Z_{j} Z_{j}-\left(P Z_{j} Z_{j}\right)+\sum_{j} P Q_{i} X_{i j}
$$

subject to

$$
Z_{j}=\min \left(\frac{X_{i j}}{a x_{i j}}, \frac{Y_{j}}{a y_{i j}}\right)
$$

As the kinks in isoquants of Leontief production function in the constraint employed in the production of gross domestic output cause difficulties in numerical computations, by following Hosoe et al. (2010) we use equation (9) which reflects the zero-profit condition. Solving these optimizations finally provides following equations in the production block. 


$$
\begin{aligned}
\text { Composite Factor: } & Y_{\mathrm{j}}=\mathrm{b}_{\mathrm{j}} C_{\mathrm{j}}^{\beta c_{\mathrm{j}}} L_{\mathrm{j}}^{\beta l_{\mathrm{j}}} \\
\text { Capital Demand: } & C_{\mathrm{j}}=\frac{\beta \mathrm{c}_{\mathrm{j}} P Y_{\mathrm{j}}}{P C_{\mathrm{j}}} Y_{\mathrm{j}} \\
\text { Composite Labour Demand: } & L_{\mathrm{j}}=\frac{\beta l_{\mathrm{j}} P Y_{\mathrm{j}}}{P L_{\mathrm{j}}} Y_{\mathrm{j}} \\
\text { Composite Labour Input: } & L_{\mathrm{j}}=\mathrm{o}_{\mathrm{j}}\left(\gamma f l_{\mathrm{j}} \mathrm{FL}_{\mathrm{j}}^{\vartheta_{\mathrm{j}}}+\gamma i l_{\mathrm{j}} I L_{\mathrm{j}}^{\vartheta_{\mathrm{j}}}\right)^{\frac{1}{\vartheta_{\mathrm{j}}}} \\
\text { Formal Labour Demand: } & F L_{\mathrm{j}}=\left[\frac{\left.\mathrm{o}_{\mathrm{j}}^{\vartheta_{\mathrm{j}}} \gamma f l_{\mathrm{j}} P L_{\mathrm{j}} \frac{1}{P F L_{\mathrm{j}}}\right]^{\frac{1}{1-\vartheta_{\mathrm{j}}}} L_{\mathrm{j}}}{\text { Informal labour Demand: }} \quad I L_{\mathrm{j}}=\left[\frac{\mathrm{o}_{\mathrm{j}}^{\vartheta_{\mathrm{j}}} \gamma i l_{\mathrm{j}} P L_{\mathrm{j}}}{P I L_{\mathrm{j}}}\right]^{\frac{1}{1-\vartheta_{\mathrm{j}}}} C_{\mathrm{j}}\right. \\
\text { Intermediate Input: } & X_{\mathrm{i}, \mathrm{j}}=\mathrm{ax}_{\mathrm{i}, \mathrm{j}} Z_{\mathrm{j}} \\
\text { Production: } & Y_{\mathrm{j}}=\mathrm{ay}_{\mathrm{j}} Z_{\mathrm{j}}
\end{aligned}
$$

Price of the $\mathrm{j}$-th Domestic Output: $\quad P Z_{\mathrm{j}}=\mathrm{ay}_{\mathrm{j}} P Y_{\mathrm{j}}+\sum_{\mathrm{i}} \mathrm{ax}_{\mathrm{i}, \mathrm{j}} P Q_{\mathrm{i}}$

where: $Y_{j}=$ composite factor produced in the second stage and used in the third stage by the $\mathrm{j}$ th sector, $b j=$ scaling coefficient in the composite factor production function, $C_{j}=$ capital demand of the $\mathrm{j}$-th sector, $L_{j}=$ composite labor input of the $\mathrm{j}$-th sector, $\beta l_{j}=$ labor share coefficient in the composite production function, $\beta c_{j}=$ capital share coefficient in the composite production function, $P Y_{j}=$ price of the $\mathrm{j}$-th composite factor, $P C_{j}=$ price of the capital demand of the $\mathrm{j}$-th sector, $o_{j}=$ scaling coefficient of the $\mathrm{j}$-th substitution, $\gamma f l_{j}=$ formal labor share coefficient in the labor input substitution, $F L_{j}=$ formal labor demand of the $\mathrm{j}$-th sector, $\vartheta_{j}=$ elasticity of substitution in the composite labour input, $\gamma i l_{j}=$ informal labor share coefficient in labor input substitution, $I L_{j}=$ informal labor demand of the j-th sector, $P L j=$ price of the j-th composite labour input, $P F L_{j}=$ price of the $\mathrm{j}$-th formal labor, $P I L_{j}=$ price of the $\mathrm{j}$-th informal labour, $X_{i, j}=$ intermediate input of the $\mathrm{i}$-th good used by the $\mathrm{j}$-th sector, $a x_{i, j}=$ input requirement coefficient of the intermediate input for a unit output of the $\mathrm{j}$-th good, $a y_{j}=$ input requirement coefficient of the $\mathrm{j}$-th composite good for a unit output of the $\mathrm{j}$-th good, $Z_{j}=$ gross domestic output the j-th sector, $P Z_{j}=$ price of the j-th gross domestic output, $P Q_{i}=$ price of the $\mathrm{i}$-th composite good.

Our model employs widely used Armington (1969) assumption, which considers imperfect substitutability between domestic goods and imports. We benefit from equation (10) which 


\section{AKBULUT, EĞEN Import Tariffs and Informal Labour Market}

represents a CES function to capture this relationship. Equation (11) and (12) shows the demand for imported and domestic goods, respectively.

$$
\begin{array}{ll}
\text { Composite Good: } & Q_{\mathrm{i}}=\gamma_{\mathrm{i}}\left(\delta \mathrm{m}_{\mathrm{i}} M_{\mathrm{i}}^{\eta \mathrm{i}}+\delta \mathrm{d}_{\mathrm{i}} D_{\mathrm{i}}^{\eta_{\mathrm{i}}}\right)^{\frac{1}{\eta_{\mathrm{i}}}} \\
\text { Imported Good: } & M_{\mathrm{i}}=\left[\frac{\gamma_{\mathrm{i}}^{\eta_{\mathrm{i}}} \delta \mathrm{m}_{\mathrm{i}} P Q_{\mathrm{i}}}{\left(1+\tau_{\mathrm{i}}^{\mathrm{m}}\right) P M_{\mathrm{i}}}\right]^{\frac{1}{1-\eta_{\mathrm{i}}}} Q_{\mathrm{i}} \\
\text { Domestic Good: } & D_{\mathrm{i}}=\left[\frac{\gamma_{\mathrm{i}}^{\eta_{\mathrm{i}}} \delta \mathrm{d}_{\mathrm{i}} P Q_{\mathrm{i}}}{P D_{\mathrm{i}}}\right]^{\frac{1}{1-\eta_{\mathrm{i}}}} Q_{\mathrm{i}}
\end{array}
$$

where: $Q_{i}=$ The i-th Armington composite good, $\gamma i=$ scaling coefficient in the Armington composite good production, $\delta m i=$ import input share coefficients in the Armington composite good production function, $M_{i}=$ the i-th imported good, $\delta d i=$ domestic good input share coefficients in the Armington composite good production function, $D_{i}=$ the $\mathrm{i}$-th domestic good, $\eta i=$ elasticity of substitution in the Armington composite good, $\tau j m=$ import tax on the $\mathrm{j}$-th good, $P M_{i}=$ price of the $\mathrm{i}$-th imported good, $P D_{i}=$ price of the $\mathrm{i}$-th domestic good.

\subsubsection{The Demand Block}

Equations in the demand block display the economic behaviours of the private sector (including households and enterprises), government and the rest of the world. Economic agents in the private sector can receive income from production factors, government transfers, and the rest of the world. The level of savings is determined by total income and the average propensity to save. On the other hand, the level of consumption emerges from the utility maximization of private sector subject to net income. Private sector maximizes its consumption subject to net income. Net income (NI) is the residual of income after subtraction of transfers from enterprises to households, private savings, income tax, foreign debt interest adjusted with exchange rate, corporation tax and public factor income from household's gross income. Relevant maximization problem is as following. Households choose optimal consumption bundle to reach maximum utility given income constraint mostly shaped by composite labour and capital endowment. For household income, we assume a uniform endowment prices of composite labour income $\left(P L E_{t}\right)$ which implicitly embeds the productivity differences between formal and informal employment. Since informal labour's income are hard to track for government, only formal labour income derives income taxes as in the equation (15). The optimization problem of households is

$$
\max _{X P_{i}} U U=\prod_{i} X_{i}^{\alpha_{i}}
$$

subject to 


$$
\sum_{i} X P_{i} P Q_{i}=N I
$$

After implementing Lagrange multiplier method, we reach private sector consumption as in the equation (12).

$$
\begin{aligned}
& \text { Private Sector Consumption: } \quad X P_{\mathrm{i}}=\frac{\alpha_{\mathrm{i}}}{P Q \mathrm{i}}(N I) \\
& \qquad H I=\sum_{\mathrm{h}}\left(L E_{\mathrm{t}} P L E_{\mathrm{t}}\right)+(C E \times P C E)+G T R H H \\
& \text { Income: } \quad+G T R E E+E E T R H+F F T R H
\end{aligned}
$$

$$
\begin{array}{ll}
\text { Net Income : } & N I=H I-E E T R H-S P-T^{\mathrm{d}}-\xi F F T R E-F T R G \\
\text { Private Savings: } & S P=\mathrm{sS}^{\mathrm{p}} H I
\end{array}
$$

where: $X P_{i}=$ private sector consumption of the $\mathrm{i}$-th good, $\alpha_{i}=$ share parameter in the utility function, $H I=$ private sector income, $E E T R H=$ transfers from enterprises to the households, $S P=$ private savings, $T^{d}=$ income tax,$\xi=$ exchange rate, $F F T R E=$ foreign debt interest, $F T R G=$ corporation tax and public factor income, $L E_{t}=$ endowment of the $\mathrm{t}$-th labor, $P L E_{t}=$ price of the t-th labour endowment, $C E=$ capital endowment, $P C E=$ price of the capital endowment, $G T R H H=$ government transfers to the households, GTREE= government transfers to the enterprises, EETRH= transfers from enterprises to the households, FFTRH= workers' foreign exchange earnings, FFTRF= enterprise exchange rate earnings, $s s p=$ average propensity of savings by the household.

The government receives revenues from income taxes, corporation taxes, indirect taxes (other than import taxes), import tariff revenues, production factor incomes and the transfers from the rest of the world. Government expenditures include purchases of goods and services, foreign debt payments and the transfer payments to households, enterprises and the social security system. The government also saves a fixed proportion of its income.

Income Taxes:

$$
T^{\mathrm{d}}=\tau^{\mathrm{d}}\left[\sum_{\mathrm{h}}\left(L E_{\mathrm{t}} P L E_{\mathrm{t}}\right)+(C E \times P C E)\right]
$$

Other Indirect Taxes: $\quad T_{\mathrm{j}}^{\mathrm{z}}=\tau_{\mathrm{j}}^{\mathrm{z}} P Z_{\mathrm{j}} Z_{\mathrm{j}}$ 


\section{AKBULUT, EĞEN Import Tariffs and Informal Labour Market}

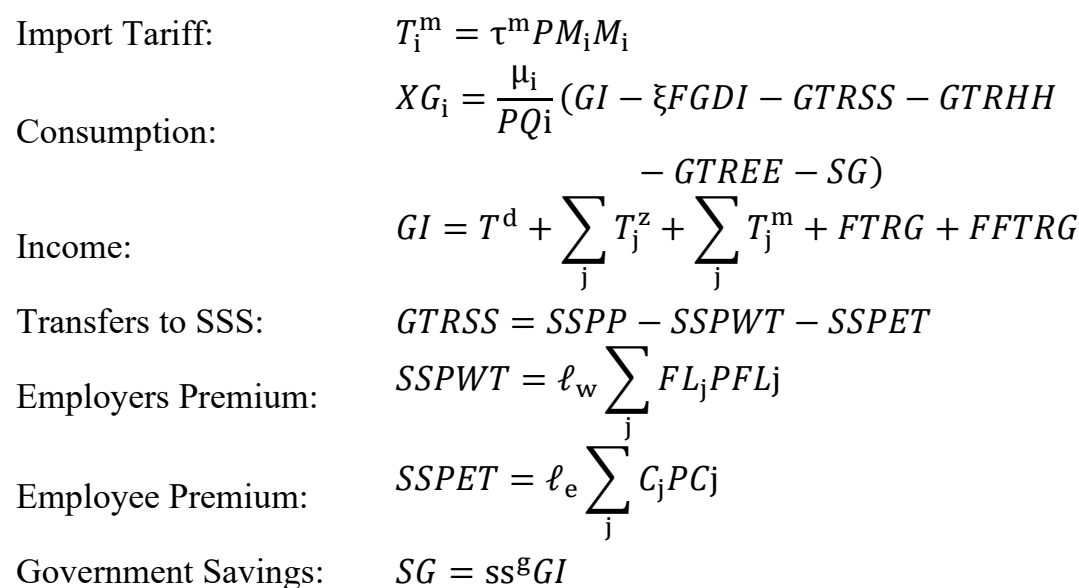

where: $\tau^{d}=$ income tax rate, $T_{j}^{Z}=$ other indirect taxes, $\tau_{j}^{Z}=$ production tax rate on the $\mathrm{j}$-th good, Tim= import tariff on the i-th good, $\tau m=$ import tariff rate, $X G_{i}=$ government consumption of the i-th good, $\mu i=$ share of the $\mathrm{i}$-th good in government consumption, $G I=$ government income, $F G D I=$ public foreign debt interest payments, GTRSS= government transfers to the social security system, $S G=$ public savings, $F F T R G=$ net unilateral transfers to government from abroad, $S S P P=$ social security system payments, $S S P W T=$ social security system employers' premium, $S S P E T=$ social security system employees' premium, $\ell_{w}=$ employer premium rate, $\ell_{e}=$ employee premium rate, $s s g=$ average propensity for savings by the government .

Total savings consists of private savings, public savings, and foreign savings. The value of foreign savings, which also reflects the trade balance, is adjusted by the exchange rate. In the model, total savings are equal to the total investments. Total Investment is:

$$
X V_{\mathrm{i}}=\frac{\lambda_{\mathrm{i}}}{P Q_{\mathrm{i}}}(S P+S G+\xi S F)
$$

where: $X V_{i}=$ demand for the i-th investment good, $\lambda_{i}=$ expenditure share of the $\mathrm{i}$-th good in total investment, $S F=$ foreign savings.

\subsubsection{The External Demand Block}

Producers decide the composition of the final commodity production, which they sell domestically or to abroad. They supply goods either domestically or externally and determine the structure of this combination according to the profit maximization. For that matter, we benefit from constant elasticity of transformation (CET) function, which assumes an imperfect substitution between the domestic goods and the exports. 


$$
\begin{array}{ll}
\text { Gross Domestic Output: } & Z_{\mathrm{i}}=\theta_{\mathrm{i}}\left(\varepsilon \mathrm{e}_{\mathrm{i}} E_{\mathrm{i}}^{\phi \mathrm{i}}+\varepsilon \mathrm{d}_{\mathrm{i}} D_{\mathrm{i}}^{\phi_{\mathrm{i}}}\right)^{\frac{1}{\phi_{\mathrm{i}}}} \\
\text { Exports: } & E_{\mathrm{i}}=\left[\frac{\theta_{\mathrm{i}}^{\phi_{\mathrm{i}}} \varepsilon \mathrm{e}_{\mathrm{i}}\left(1+\tau_{\mathrm{i}}^{\mathrm{z}}\right) P Z_{\mathrm{i}}}{P E_{\mathrm{i}}}\right]^{\frac{1}{1-\phi_{\mathrm{i}}}} Z_{\mathrm{i}} \\
\text { Domestic Good } & D_{\mathrm{i}}=\left[\frac{\theta_{\mathrm{i}}^{\phi_{\mathrm{i}}} \varepsilon \mathrm{d}_{\mathrm{i}} P Z_{\mathrm{i}}}{P D_{\mathrm{i}}}\right]^{\frac{1}{1-\phi_{\mathrm{i}}}} Z_{\mathrm{i}}
\end{array}
$$

where: $\theta_{i}=$ scaling coefficient of the $\mathrm{i}$-th gross domestic output, $\varepsilon e i=$ export share coefficient for the $\mathrm{i}$ - th transformation, $E_{i}=$ the $\mathrm{i}$-th exported good, $\phi_{i}=$ elasticity of transformation of the i-th good transformation production function, $\varepsilon d_{i}=$ domestic share coefficient for the i-th transformation, $P E_{i}=$ price of the i-th exported good.

We utilize from equations (30) and (31) to distinguish the export and import prices concerning world prices. In this process, we also employ a small country assumption for Turkey such that does not have significant influences on world prices. Finally, we employ equation (32) to inject the balance of payments relations to the model.

$$
\begin{array}{ll}
\text { Export Prices: } & P E_{\mathrm{i}}=\xi P W_{\mathrm{i}}^{\mathrm{e}} \\
\text { Import Prices: } & P M_{\mathrm{i}}=\xi P W_{\mathrm{i}}^{\mathrm{m}} \\
\text { The Balance of Payment } & \sum_{\mathrm{i}} P W_{\mathrm{i}}^{\mathrm{e}} E_{\mathrm{i}}+S F=\sum_{\mathrm{i}} P W_{\mathrm{i}}^{\mathrm{m}} M_{\mathrm{i}} \\
\text { Constraint: } &
\end{array}
$$

where: $P W_{i}^{e}=$ export price in terms of foreign currency, $P W_{i}^{m}=$ import price in terms of foreign currency.

\subsubsection{The Market Clearing Conditions}

In this block, we set the equations that satisfy the market clearing conditions. Goods market equilibrium indicates that the total supply of Armington composite good is either used as intermediate and investment goods or consumed by the private sector and the government. Equilibrium conditions of each factor market require that the total initial endowments of the factors are equal to the total demands of them.

Goods Market Equilibrium:

$$
\begin{array}{ll}
\text { Goods Market Equilibrium: } & X P_{\mathrm{i}}+X G_{\mathrm{i}}+X V_{\mathrm{i}}+\sum_{\mathrm{j}} X_{\mathrm{i}, \mathrm{j}}=Q_{\mathrm{i}} \\
\text { Labour Market Equilibrium: } & \sum_{\mathrm{j}} F L_{\mathrm{j}}+I L_{\mathrm{j}}=\sum_{\mathrm{t}} L E_{\mathrm{t}}
\end{array}
$$




\section{AKBULUT, EĞEN Import Tariffs and Informal Labour Market}

Capital Market Equilibrium: $\quad \sum_{\mathrm{j}} C_{\mathrm{j}}=C E$

The above listed simultaneous equations are solved through the General Algebraic Modelling System (GAMS) software to obtain the parameters of the benchmark equilibrium. In that process, we utilize a SAM for Turkey, which is constructed to be compatible with our model. We calibrated some of the parameters endogenously or by deriving from the SAM. For the remaining parameters, we use presumptions.

Detailed calibration results and input requirement coefficients are shown in Appendix. To reflect the differences of substitution between informal and formal labour across sectors, we set the following elasticities for each sector considering the ratio of informal labour to total employment in the SAM: agriculture (0.32), mining (0.04), industry (0.07), energy (0.09), construction (0.08) and services (0.05). Here we assume a higher income substitution in the agriculture sector and from these elasticities the highest calibrated informal labour share coefficient in labour input substitution $\left(\gamma i l_{j}\right)$ are found in agriculture as well by 0.60 .

As the main focus in the paper is to see the effects of import tariffs on employment, we use average tariffs rate data from World Integrated Trade Solution (WITS) of World Bank for import tariff rate in agriculture, mining and industry. The highest tariff rate is in the agriculture sector by $18 \%$ and the lowest tariff rate is approximately $1 \%$ in mining. The industry tariff rate of $6 \%$ is also set for energy, construction and services.

After reaching an optimal solution that satisfies the benchmark equilibrium, we apply different import tariff policy scenarios to test the effects of changes in the import tariff rates on formal and informal labour markets. We present the evaluation of the results in the next section.

\section{The Import Tariff Policy Results}

In this section, we evaluate two different policy scenario to test the impacts of the changes in import tariffs on the labour market. In the first scenario, we apply $20 \%, 40 \%$, and $60 \%$ reductions of import tariff rate to the benchmark equilibrium from which we obtained the calibration of parameters. In the second scenario, we test the effects of $20 \%, 40 \%$, and $60 \%$ increase in import tariff rates. Table 1 reports the \% changes in total, formal, and informal labour after the trade policy reforms.

\subsection{Scenario 1: Decrease in Import Tariff Rate}

The results of scenario 1 indicate that the decrease in import tariff rate causes an increase in informal labour. Informal labour grows in all sectors except services. $60 \%$ import tariff rate cut leads to falls in employment by $0.48 \%$ in the service sector. On the other hand, the largest increase in informal employment arises in the industrial sector by $2.80 \%$. 
Table 1. The Changes in Labour Market after Policy Scenarios (\%)

\begin{tabular}{|c|c|c|c|c|c|c|c|}
\hline \multicolumn{8}{|c|}{ Scenario 1: Decrease in Import Tariff Rate } \\
\hline & Agriculture & Mining & Industry & Energy & Construction & Services & Total \\
\hline \multicolumn{8}{|c|}{ Informal Labour $I L_{j}$} \\
\hline$\% 20$ Reduction & 0.29 & 0.76 & 0.89 & 0.11 & 0.04 & -0.15 & 0.17 \\
\hline$\% 40$ Reduction & 0.59 & 1.54 & 1.82 & 0.23 & 0.08 & -0.31 & 0.34 \\
\hline$\% 60$ Reduction & 0.89 & 2.35 & 2.80 & 0.35 & 0.12 & -0.48 & 0.51 \\
\hline \multicolumn{8}{|c|}{ Formal Labour $F L_{j}$} \\
\hline$\% 20$ Reduction & -5.00 & 0.70 & 0.79 & -0.09 & -0.08 & -0.21 & -0.05 \\
\hline \%40 Reduction & -10.05 & 1.43 & 1.62 & -0.18 & -0.17 & -0.43 & -0.10 \\
\hline \%60 Reduction & -15.15 & 2.18 & 2.49 & -0.27 & -0.26 & -0.66 & -0.15 \\
\hline \multicolumn{8}{|l|}{ Total Labour $L_{j}$} \\
\hline$\% 20$ Reduction & -0.07 & 0.71 & 0.81 & -0.05 & -0.06 & -0.21 & -0.01 \\
\hline \%40 Reduction & -0.15 & 1.44 & 1.65 & -0.10 & -0.13 & -0.42 & -0.02 \\
\hline \%60 Reduction & -0.25 & 2.20 & 2.53 & -0.15 & -0.20 & -0.64 & -0.03 \\
\hline \multicolumn{8}{|c|}{ Scenario 2: Increase in Import Tariff Rate } \\
\hline \multicolumn{8}{|c|}{ Informal Labour $I L_{j}$} \\
\hline \%20 Reduction & -0.29 & -0.73 & -0.85 & -0.11 & -0.04 & 0.15 & -0.16 \\
\hline \%40 Reduction & -0.57 & -1.44 & -1.67 & -0.21 & -0.08 & 0.29 & -0.32 \\
\hline \%60 Reduction & -0.85 & -2.13 & -2.46 & -0.31 & -0.11 & 0.43 & -0.47 \\
\hline \multicolumn{8}{|c|}{ Formal Labour $F L_{j}$} \\
\hline \%20 Reduction & 4.94 & -0.68 & -0.76 & 0.08 & 0.08 & 0.20 & 0.05 \\
\hline \%40 Reduction & 9.82 & -1.35 & -1.50 & 0.16 & 0.15 & 0.40 & 0.10 \\
\hline \%60 Reduction & 14.64 & -1.99 & -2.20 & 0.24 & 0.23 & 0.59 & 0.14 \\
\hline \multicolumn{8}{|l|}{ Total Labour $L_{j}$} \\
\hline \%20 Reduction & 0.06 & -0.69 & -0.78 & 0.05 & 0.06 & 0.20 & 0.01 \\
\hline \%40 Reduction & 0.10 & -1.35 & -1.52 & 0.09 & 0.12 & 0.39 & 0.02 \\
\hline \%60 Reduction & 0.14 & -2.00 & -2.24 & 0.13 & 0.17 & 0.58 & 0.03 \\
\hline
\end{tabular}

Import tariff reduction causes a decrease in the total formal labour. $60 \%$ of import tariff cut causes a decrease in formal employment by $0.15 \%$. Contrarily, formal labour in mining, industry, expands. However, increasing employment in those sectors does not compensate for the employment losses from the other sectors.

Similar to the changes in formal labour, import tariff reduction leads mostly to a decrease in total employment, as well. Import tariff rates have to be cut down by $60 \%$ to achieve slight employment gains of $0.03 \%$. However, employment expansion comes for the most part from the informal sector. The decline in total employment arises from the decrease in employment in the agriculture, energy, construction, and service sectors. On the other hand, we found that 
reduction of import tariff rates would lead to an increase in the total employment in mining and industry. Accordingly, a $60 \%$ decrease in import tariff rates increases the employment in mining and industry by $2.20 \%, 2.53 \%$, respectively.

\subsection{Scenario 2: Increase in Import Tariff Rate}

The results of scenario 2 indicate that the increase in import tariff rate causes a decrease in informal labour. $60 \%$ increase of import tariff rate decrease the informal labour in agriculture, mining, industry, energy, and construction services by $0.85 \%, 2.13 \%, 2.46 \%, 0.31 \%$, and $0.11 \%$. The increase in the import tariff rate will cause an increase in informal labour only in the service sector. $60 \%$ increase in the import tariff rate will increase the informal labour in the service sector by $0.43 \%$.

Parallel to the effects on formal employment, increase in import tariff rates will cause expansions in total employment. $60 \%$ increase in import tariff rate will increase total employment by $0.03 \%$. The increase in total employment mostly arises from the agriculture, energy, constructions and services. On the other hand, a $60 \%$ increase in import tariff rate will decrease total employment in mining and industry by $2.00 \%$ and $2.24 \%$.

\section{Conclusion}

Trade liberalization policies have been used widely, especially after the 1980s. In that process, governments usually benefit from import tariff reduction as it is easy to operate. Turkey, in the process of the integration to the European Union, has adopted liberalized trade policies, too. However, the effects of this process on the entire economy are controversial. This study tries to analyse the effects of the changes in import tariff rates on the labour market by taking into account both formal and informal sectors in Turkey. The consequences of the labour market are crucial as Turkey faces both the difficulties regarding high unemployment rates and informality. The level of informal labour in the agricultural sector is particularly remarkable. From that point forth, we base our study on the impacts of changing import tariff rates on employment on a sectorial basis.

As a methodology, we base our analysis on the CGE framework which employs simultaneous equation systems which allow us to observe the effects of different policy reforms relative to benchmark equilibrium. By doing so, we are also able to get rid of the lack of longterm data which is required to make reliable estimations in empirical studies based on time series. We also contribute to the literature by constructing an updated SAM for Turkey which can also be used in future economic studies depending on CGE models.

Our policy scenario results indicate that reduction in import tariff rates will cause an increase in informal labour while it decreases formal labour and total employment. In a parallel manner with the results of the first scenario, the second policy scenario results indicate that increase in 
import tariff rates will decrease the level of informal labour, while it increases formal labour and total employment. If we focus on the labour market on a sectorial basis, we observe that a decrease in total formal labour after the policy reform of the second scenario arise only in the mining and industry sectors. However, as employment in agriculture composes the largest part of informal labour, the relevant result is helpful since the highest increase formal labour is in the agricultural sector. Uniform tariff policy of either increase or decrease the rate does not affect the sectors in the same manner. Changing the tariff rate leads to an increase in employment in some sectors while a decrease in the others. In that sense, selective tariff policy which applies the changes of tariff rates in the sectors that could expand employment while conserving the rate in the others would be more effective on employment. Nevertheless, our findings favour protective trade policy in terms of import tariff rates for Turkey to achieve positive outcomes on the labour market.

\section{Declaration of Conflicting Interests}

The authors declared no potential conflicts of interest with respect to the research, authorship and/or publication of this article.

\section{Funding}

The authors received no financial support for the research, authorship and/or publication of this article.

\section{Appendix}

Table A1 Unregistered Employment Rate in Turkey (\%)

\begin{tabular}{|l||c|c|c|}
\hline Year & Total & Agriculture & Non-agriculture \\
\hline \hline $\mathbf{2 0 1 4}$ & 35.0 & 82.3 & 22.3 \\
\hline $\mathbf{2 0 1 5}$ & 33.6 & 81.2 & 21.2 \\
\hline $\mathbf{2 0 1 6}$ & 33.5 & 82.1 & 21.7 \\
\hline $\mathbf{2 0 1 7}$ & 34.0 & 83.2 & 22.1 \\
\hline
\end{tabular}

$\$ 2017$ data is the average of the period January-November 2017.

Source: TURKSTAT, Labour Force Statistics 
Table A2 The Structure of the Social Accounting Matrix

\begin{tabular}{|c|c|c|c|c|c|c|c|c|c|c|c|c|c|c|}
\hline & $\begin{array}{c}\text { Goods and } \\
\text { Services }\end{array}$ & $\begin{array}{l}\text { Formal } \\
\text { Labour }\end{array}$ & $\begin{array}{l}\text { Informal } \\
\text { Labour }\end{array}$ & Capital & Social Security System & Households & Enterprises & Government & \begin{tabular}{|c|} 
Indirect \\
Taxes
\end{tabular} & $\begin{array}{l}\text { Import } \\
\text { Tariff }\end{array}$ & $\begin{array}{c}\text { Private } \\
\text { Capital } \\
\text { Accumulation } \\
\end{array}$ & $\begin{array}{c}\text { Public } \\
\text { Capital } \\
\text { Accumulation } \\
\end{array}$ & External & Total \\
\hline $\begin{array}{l}\text { Goods and } \\
\text { Services } \\
\end{array}$ & $\begin{array}{c}\text { intermediate } \\
\text { Input }\end{array}$ & & & & & $\begin{array}{c}\begin{array}{c}\text { household } \\
\text { consumption }\end{array} \\
\end{array}$ & & $\begin{array}{l}\begin{array}{l}\text { government } \\
\text { consumption }\end{array} \\
\end{array}$ & & & $\begin{array}{c}\text { private } \\
\text { investment }\end{array}$ & $\begin{array}{c}\text { public } \\
\text { investment }\end{array}$ & exports & demand \\
\hline $\begin{array}{l}\text { Formal } \\
\text { Labour }\end{array}$ & $\begin{array}{c}\text { payments to the } \\
\text { formal labour }\end{array}$ & & & & & & & & & & & & & $\begin{array}{c}\text { formal labour } \\
\text { income }\end{array}$ \\
\hline $\begin{array}{l}\text { Informal } \\
\text { Labour }\end{array}$ & $\begin{array}{c}\text { payments to the } \\
\text { Inf. formal } \\
\text { labour }\end{array}$ & & & & & & & & & & & & & $\begin{array}{c}\text { informal } \\
\text { labour } \\
\text { income } \\
\end{array}$ \\
\hline Capital & $\begin{array}{c}\text { payments to the } \\
\text { capital }\end{array}$ & & & & & & & & & & & & & capital income \\
\hline $\begin{array}{c}\text { Social Security } \\
\text { System }\end{array}$ & $\begin{array}{l}\text { employee } \\
\text { premium }\end{array}$ & $\begin{array}{c}\text { employers } \\
\text { premium }\end{array}$ & & & & & & $\begin{array}{l}\text { deficit } \\
\text { transfers }\end{array}$ & & & & & & \begin{tabular}{|c|} 
social security \\
system \\
income
\end{tabular} \\
\hline Households & & $\begin{array}{c}\text { net formal } \\
\text { labour } \\
\text { income }\end{array}$ & \begin{tabular}{|c|} 
net \\
informal \\
labour \\
income \\
\end{tabular} & & $\begin{array}{c}\text { social } \\
\text { security } \\
\text { payments }\end{array}$ & & \begin{tabular}{|c|} 
transfers to \\
the \\
households
\end{tabular} & $\begin{array}{c}\text { public } \\
\text { transfers to } \\
\text { the households }\end{array}$ & & & & & $\begin{array}{l}\text { worker's } \\
\text { foreign } \\
\text { exchange } \\
\text { earnings } \\
\end{array}$ & $\begin{array}{l}\text { household } \\
\text { income }\end{array}$ \\
\hline Enterprises & & & & $\begin{array}{c}\text { capital } \\
\text { income }\end{array}$ & & & & \begin{tabular}{|c|} 
production \\
promotions + \\
domestic debt \\
interest \\
payment \\
\end{tabular} & & & & & $\begin{array}{l}\text { enterprise } \\
\text { foreign } \\
\text { exchange } \\
\text { earnings }\end{array}$ & $\begin{array}{l}\text { enterprise } \\
\text { income }\end{array}$ \\
\hline Government & & & & & & direct taxes & \begin{tabular}{|c|} 
corporation \\
taxes + \\
public factor \\
income
\end{tabular} & & $\begin{array}{c}\text { indirect } \\
\text { taxes }\end{array}$ & $\begin{array}{c}\text { import } \\
\text { tariffs }\end{array}$ & & & $\begin{array}{c}\text { net } \\
\text { unilateral } \\
\text { transfers }\end{array}$ & $\begin{array}{c}\text { government } \\
\text { income }\end{array}$ \\
\hline
\end{tabular}


Review of Economic Analysis 13 (2021) 213-234

Table A2 Continued

\begin{tabular}{|c|c|c|c|c|c|c|c|c|c|c|c|c|c|c|}
\hline & $\begin{array}{c}\text { Goods and } \\
\text { Services }\end{array}$ & $\begin{array}{l}\text { Formal } \\
\text { Labour }\end{array}$ & $\begin{array}{c}\text { Informal } \\
\text { Labour }\end{array}$ & Capital & Social Security System & Households & Enterprises & Government & $\begin{array}{c}\text { Indirect } \\
\text { Taxes }\end{array}$ & $\begin{array}{c}\text { Import } \\
\text { Tariff }\end{array}$ & $\begin{array}{c}\text { Private } \\
\text { Capital } \\
\text { Accumulation }\end{array}$ & $\begin{array}{c}\text { Public } \\
\text { Capital } \\
\text { Accumulation }\end{array}$ & External & Total \\
\hline $\begin{array}{c}\text { Indirect } \\
\text { Taxes }\end{array}$ & $\begin{array}{l}\text { production, } \\
\text { sales, export } \\
\text { taxes }\end{array}$ & & & & & & & & & & & & & $\begin{array}{l}\text { indirect } \\
\text { taxes }\end{array}$ \\
\hline $\begin{array}{c}\text { Import } \\
\text { Tariff }\end{array}$ & $\begin{array}{l}\text { import } \\
\text { tariffs }\end{array}$ & & & & & & & & & & & & & $\begin{array}{l}\text { import } \\
\text { tariffs }\end{array}$ \\
\hline $\begin{array}{c}\text { Private Capital } \\
\text { Accumulation }\end{array}$ & & & & & & $\begin{array}{l}\text { private } \\
\text { savings }\end{array}$ & & & & & & & & $\begin{array}{c}\text { finance of } \\
\text { private } \\
\text { investments }\end{array}$ \\
\hline $\begin{array}{l}\text { Public Capital } \\
\text { Accumulation }\end{array}$ & & & & & & \begin{tabular}{|c|} 
private \\
savings \\
investment \\
difference
\end{tabular} & & $\begin{array}{l}\text { public } \\
\text { savings }\end{array}$ & & & & & $\begin{array}{l}\text { foreign } \\
\text { savings }\end{array}$ & $\begin{array}{c}\text { finance of } \\
\text { public } \\
\text { investments }\end{array}$ \\
\hline External & imports & & & & & & \begin{tabular}{|c|} 
foreign debt \\
interest \\
payments + \\
net profit \\
transfers
\end{tabular} & $\begin{array}{c}\text { public foreign } \\
\text { debt interest } \\
\text { payment }\end{array}$ & & & & & & $\begin{array}{l}\text { external } \\
\text { income }\end{array}$ \\
\hline Total & total supply & $\begin{array}{l}\text { formal } \\
\text { labour } \\
\text { costs }\end{array}$ & \begin{tabular}{|c|} 
informal \\
labour \\
costs \\
\end{tabular} & $\begin{array}{c}\text { capital } \\
\text { costs }\end{array}$ & $\begin{array}{c}\text { Social security } \\
\text { system expenditures }\end{array}$ & \begin{tabular}{|c|} 
household \\
expenditures
\end{tabular} & \begin{tabular}{|c|} 
enterprises \\
expenditures
\end{tabular} & $\begin{array}{c}\text { government } \\
\text { expenditures }\end{array}$ & $\begin{array}{c}\text { indirect } \\
\text { taxes }\end{array}$ & $\begin{array}{c}\text { import } \\
\text { tariff }\end{array}$ & $\begin{array}{c}\text { private } \\
\text { investments }\end{array}$ & $\begin{array}{c}\text { public } \\
\text { investments }\end{array}$ & $\begin{array}{c}\text { external } \\
\text { expenditures }\end{array}$ & \\
\hline
\end{tabular}


AKBULUT, EĞEN Import Tariffs and Informal Labour Market

Table A3 Calibration of the Parameters

\begin{tabular}{|c|c|c|c|c|c|c|}
\hline & Agriculture & Mining & Industry & Energy & Construction & Services \\
\hline$\overline{b_{j}}$ & 1.84 & 1.93 & 1.90 & 1.65 & 1.85 & 1.96 \\
\hline$\beta l_{j}$ & 0.30 & 0.36 & 0.34 & 0.20 & 0.31 & 0.39 \\
\hline$\beta c_{j}$ & 0.70 & 0.64 & 0.66 & 0.80 & 0.69 & 0.61 \\
\hline$o_{j}$ & 4.57 & 2.29 & 2.90 & 6.49 & 3.57 & 2.17 \\
\hline$\gamma f l_{j}$ & 0.40 & 0.91 & 0.84 & 0.80 & 0.82 & 0.88 \\
\hline$\gamma i l_{j}$ & 0.60 & 0.08 & 0.16 & 0.20 & 0.18 & 0.12 \\
\hline $\boldsymbol{\vartheta}_{j}$ & 0.32 & 0.04 & 0.07 & 0.09 & 0.08 & 0.05 \\
\hline$a y_{j}$ & 0.65 & 0.60 & 0.29 & 0.26 & 0.38 & 0.63 \\
\hline$\gamma_{i}$ & 1.65 & 2.12 & 2.06 & 1.15 & 1.01 & 1.40 \\
\hline$\delta m_{i}$ & 0.24 & 0.63 & 0.42 & 0.06 & 0.00 & 0.15 \\
\hline$\delta d_{i}$ & 0.76 & 0.37 & 0.58 & 0.94 & 1 & 0.84 \\
\hline$\eta_{i}$ & 0.5 & 0.5 & 0.5 & 0.5 & 0.5 & 0.5 \\
\hline$\alpha_{i}$ & 0.07 & 0.02 & 0.28 & 0.01 & 0.02 & 0.60 \\
\hline$\tau^{m}$ & 0.18 & 0.01 & 0.06 & 0.06 & 0.06 & 0.06 \\
\hline$\tau_{j}^{Z}$ & 0.02 & 0.16 & 0.09 & 0.06 & 0.04 & 0.04 \\
\hline$\mu_{i}$ & 0.0 & 0.0 & 0.04 & 0.03 & 0.00 & 0.93 \\
\hline$\lambda_{i}^{p}$ & 0.03 & 0.01 & 0.28 & 0.08 & 0.48 & 0.12 \\
\hline $\boldsymbol{\theta}_{\boldsymbol{i}}$ & 3.05 & 1.98 & 1.94 & 7.35 & 5.74 & 2.97 \\
\hline$\varepsilon \boldsymbol{e}_{i}$ & 0.81 & 0.69 & 0.62 & 0.95 & 0.93 & 0.81 \\
\hline$\varepsilon d_{i}$ & 0.19 & 0.31 & 0.38 & 0.05 & 0.07 & 0.19 \\
\hline$\phi i$ & 1.5 & 1.5 & 1.5 & 1.5 & 1.5 & 1.5 \\
\hline
\end{tabular}


Review of Economic Analysis 13 (2021) 213-234

Table A4 Other Parameters

\begin{tabular}{|c||l|c|}
\hline \multicolumn{1}{|c||}{ Parameters } & \multicolumn{1}{|c|}{ Definition } & Value \\
\hline \hline $\boldsymbol{s \boldsymbol { s } ^ { \boldsymbol { p } }}$ & Average propensity for savings by the household & 0.15 \\
\hline $\boldsymbol{s \boldsymbol { s }}^{\boldsymbol{g}}$ & Average propensity for savings by the government & 0.11 \\
\hline $\boldsymbol{\ell}_{\boldsymbol{w}}$ & Employer premium rate & 0.09 \\
\hline $\boldsymbol{\ell}_{\boldsymbol{e}}$ & Employee premium rate & 0.08 \\
\hline
\end{tabular}

Table A5 Input Requirement Coefficients

\begin{tabular}{|l||c|c|c|c|c|c|}
\hline \multicolumn{1}{|c|}{$\boldsymbol{a x} \boldsymbol{x}_{\boldsymbol{i}, \boldsymbol{j}}$} & Agriculture & Mining & Industry & Energy & Construction \\
\hline \hline Agriculture & 0.17 & 0.00 & 0.07 & 0.00 & 0.00 \\
\hline Mining & 0.00 & 0.06 & 0.06 & 0.19 & 0.02 \\
\hline Industry & 0.12 & 0.14 & 0.38 & 0.02 & 0.00 \\
\hline Energy & 0.01 & 0.03 & 0.05 & 0.45 & 0.00 \\
\hline Construction & 0.00 & 0.00 & 0.00 & 0.02 & 0.02 \\
\hline Services & 0.05 & 0.16 & 0.14 & 0.06 & 0.16 & 0.12 \\
\hline
\end{tabular}

\section{References}

Alia, D. Y., Ndjana, W.F. \& Voufo E. N. (2015), Economic policies and informal sector performance in Cameroon: A CGE analysis. In Ministry of Economy, Planning and Regional Development. Cameroon.

Anderson, J. E. \& Wincoop, E. (2004), Trade costs. Journal of Economic Literature, 42, 691751 .

Armington, P. S. (1969), A theory of demand for products distinguished by place of production. IMF Staff Papers, No. 16.

Bacchetta, M., Ernst,E. \& Bustamante, J. P. (2009), Globalization and informal jobs in developing countries. A Joint Study of the ILO and the Secretariat of the WTO. https://www.wto.org/english/res_e/booksp_e/jobs_devel_countries_e.pdf

Chaudhuri, S. \& Banerjee, D. (2007), Economic liberalization, capital mobility and informal wage in a small open economy: A theoretical analysis, Economic Modelling, 24, 924-940. doi:10.1016/j.econmod.2007.03.003. 
Chitiga, M. \& Mabugu, R. (2005), The impact of tariff reduction on poverty in Zimbabwe: A CGE Top-Down Approach, South African Journal of Economic and Management Sciences, $8,102-116$.

Cirera, X., Willenbockel, D. \& Lakshman R. W. D. (2014), Evidence on the impact of tariff reductions on employment in developing countries: A systematic review, Journal of Economic Surveys, 28, 449-471. doi:10.1111/joes.12029.

Currie, J. \& Harrison, A. E. (1997), Sharing the costs: The impact of trade reform on capital and labour in Morocco, Journal of Labour Economics, 15, $44-71$.

Danopoulos, C. P. \& Znidaric, B. (2007), Informal economy, tax evasion, and poverty in a democratic setting: Greece, Mediterranean Quarterly, 18, 68-84. doi:10.1215/104745522007-006

Davies. R. \& Thurlow, J. (2010), Formal-informal economy linkages and unemployment in South Africa, South African Journal of Economics, 78, 437-459.

Eaton, J. \& Kortum, S. (2002), Technology, geography, and trade, Econometrica, 70, 17411779.

Erero, J. L. \& Bonga-Bonga, L. (2018). Effects of reducing tariffs in the Democratic Republic of Congo (DRC): A CGE Analysis. The Journal of Developing Areas, 52, 55-72.

Erten, H. (2009), Türkiye için sosyal hesaplar matrisi üretme yöntemi ve istihdam üzerine bir hesaplanabilir genel denge modeli uygulamas1, Dissertation of Turkish Republic DPT, Ankara.

EU Commission (1998), Communication from the Commission on Undeclared Work. COM (98) 219 final, 7 April 1998. [EU Commission - COM Document]. http://aei.pitt.edu/5111/1/5111.pdf

Goldberg, P. K. \& Pavcnik, N. (2003). The response of the informal sector to trade liberalization, NBER Working Paper Series No. 9443.

Helpman, E., Melitz, M. \& Rubinstein, Y. (2008), Estimating trade flows: Trading partners and trading volumes, Quarterly Journal of Economics, 123, 441-487.

Hosoe, N., Gasawa, K. \& Hashimoto, H. (2010), Textbook of computable general equilibrium modelling, NY: Palgrave Macmillan.

ILO. (1972), Employment, incomes and equality: A strategy for increasing productive employment in Kenya. Report of an Inter-Agency Team Financed by the UNDP and Organized by the ILO. Geneva.

Khan, H. A. (2005), Assessing poverty impact of trade liberalization policies: A generic macroeconomic computable general equilibrium model for South Asia, ADB Institute Discussion Paper, No. 22.

Lofgren, H. (2000), Exercises in general equilibrium modeling using GAMS, Microcomputers in Policy Research. Washington, D.C.: IFPRI. 
Marjit, S. \& Kar. S. (2007), The urban informal sector and poverty: Effects of trade reform and capital mobility in India. MPIA Working Paper, 2007-09. $\mathrm{http}: / /$ ssrn.com/abstract $=968655$

Munro, L. (2011), A literature review on trade and informal labour markets in developing countries, OECD Trade Policy Working Papers No. 132, OECD Publishing. http://dx.doi.org/10.1787/5kg3nh4xwxr0-en

Mohammed, T. (2016), A CGE analysis of the economic impact of trade liberalization on the Algerian economy, European Journal of Sustainable Development, 5, 397-408.

Nikulin, D. (2016), How to define and measure informal employment in developed countries? A case of Poland. GUT Faculty of Management and Economics Working Paper Series A. No. 5/2016(35).

Raihan, S. (2010), Welfare and poverty impacts of trade liberalization: A dynamic CGE microsimulation analysis, International Journal of Microsimulation, 3, 123-126.

Saint-Paul, G. (1996), Dual Labour Markets: A Macroeconomic Perspective, MIT Press.

Siddiqui, R., Siddiqui, R. \& Iqbal, Z. (1999), The impact of tariff reforms on income distribution in Pakistan: A CGE-based analysis, The Pakistan Development Review, 38, 789-804.

Siddiqui, R. \& Iqbal, Z. (2001), Tariff reduction and functional income distribution in Pakistan: A CGE model, MIMAP Technical Paper Series No. 10.

Spiro, P. S. (2005), Tax policy and the underground economy, In Bajada, C., Schneider, F., (Eds.), Size, causes and consequences of the underground economy, pp. 179-201. Aldershot, UK: Ashgate Publishing.

Telli, Ç. (2004), Sosyal hesaplar matrisi uretme yontemi ve Türkiye uygulaması, Dissertation of Turkish Republic DPT, Ankara.

TURKSTAT. Turkish Statistical Institute, http://www.turkstat.gov.tr.

Waugh, M. E. (2010), International trade and income differences, American Economic Review, 100, 2093-2124. doi:10.1257/aer.100.5.2093.

World Bank 2017, World Development Indicators (WDI,. Trade (\% of GDP) https://data.worldbank.org/indicator/NE.TRD.GNFS.ZS 